\title{
Hydrographic and hydrochemical characteristics of the landslide lake Jazerske (Spišska Magura, Northern Slovakia)
}

\author{
Tadeusz Molenda \\ University of Silesia, Faculty of Earth Sciences, Będzińska 60, 41-200 Sosnowiec, Poland, e-mail: tadeusz.molenda@us.edu.pl
}

\begin{abstract}
This article presents the hydrographic and hydrochemical characteristics of this lake. Lake Jazerske is located in the Western Carpathians (Spiš Magura) in northern Slovakia. It occupies a depression that was formed at the foot of the main scarp of a landslide. Below the lake, there are small intercolluvial depressions that have been transformed into wetlands (peat bogs). The studied lake is very small. Its area is $3600 \mathrm{~m}^{2}$ and its length is $85 \mathrm{~m}$. The maximum depth of the lake is $7.2 \mathrm{~m}$ and its capacity is $17000 \mathrm{~m}^{3}$. The lake is supplied by an inflow of groundwater via fractured aquifers. During periods of heavy rainfall and snow melting, the lake is also supplied by the water from surface runoff. On the main slope of the landslides, traces of ephemeral courses were also found. During the periods of increased supply (spring snow melting, summer rainfall), the outflow of water from the lake occurs both on the surface and underground. In terms of its hydrochemistry, the lake water represents the four-ion type - bicarbonate-sulphate-calcium-magnesium. The concentrations of various ions is characteristic of the shallow groundwater of the Carpathian flysch. The predominant cation, the average concentration of which is $52 \mathrm{mg} \mathrm{dm}^{-3}$, is calcium. The dominant anion is carbohydrates with an average concentration of $163 \mathrm{mg} \mathrm{dm}^{-3}$. What is interesting is the very low levels of chlorides, which do not exceed $2 \mathrm{mg} \mathrm{dm}^{-3}$. The electrolytic conductivity of the water flowing out of the lake ranged from 290 to $328 \mu \mathrm{S} \mathrm{cm}^{-1}$.
\end{abstract}

Key words: landslide lake, hydrochemistry, bathymetry map, landslide peat bog, Western Carpathian, Northern Slovakia

\section{Introduction}

Moving waste covers and subsurface loose and compact rocks that result from gravitational movements cause the transformation of slopes. The most common process of the relatively rapid movement of waste and rock masses down a slope is sliding. In the Western Carpathians, mass movement processes are common (Schramm 1925; Kardaszewska 1968; Bober 1984; Margielewski 1999; Alexandrowicz and Margielewski 2010). Landslide lakes may develop in their aftermath (Nowalnicki 1971; Pánek et al. 2007; Zatorski et. al 2016). Such lakes may have different origins and may represent one of four genetic types. The first type includes lakes that form in depressions at the foot of the main landslide slope. The other genetic types include lakes that form in intercolluvial depressions and in fissure hollows in ridge ditches. The last genetic type is represented by barrier lakes that are formed by damming a river valley with colluvial material (Alexandrowicz 1993, 1997; Margielewski 2014; Molenda and Błońska 2015). Despite numerous landslides, lakes that have developed as a result of landslide processes are rare in the Western Carpathians (Schramm 1925; Kardaszewska 1968; Zatorski et. al. 2016). Most landslide lakes disappear rapidly due to their small area and depth. As a result of siltation and the development of hydrophilic vegetation, shallow landslide lakes are transformed into wetlands (Margielewski 2014). Against this background, Lake Jazerske is a unique water body. The purpose of the article is to present the hydrographic and hydrochemical characteristics of Lake Jazerske - the deepest landslide lake in the Beskidy Mountains.

\section{Study area}

Lake Jazerske is located in the Western Carpathians (Spiš Magura) in northern Slovakia (Fig. 1). The geometrical centre of the lake is marked by coordinates $\left(49^{\circ} 16^{\prime} 58^{\prime \prime} \mathrm{N}, 20^{\circ} 20^{\prime} 48^{\prime \prime} \mathrm{E}\right)$. In terms of its geological structure, the lake catchment is located within a flysch zone. It is primarily composed of Zuberec sandstones and mudstone layers (Geologic map of the SR). The topography of the lake basin and the adjacent area is typi- 


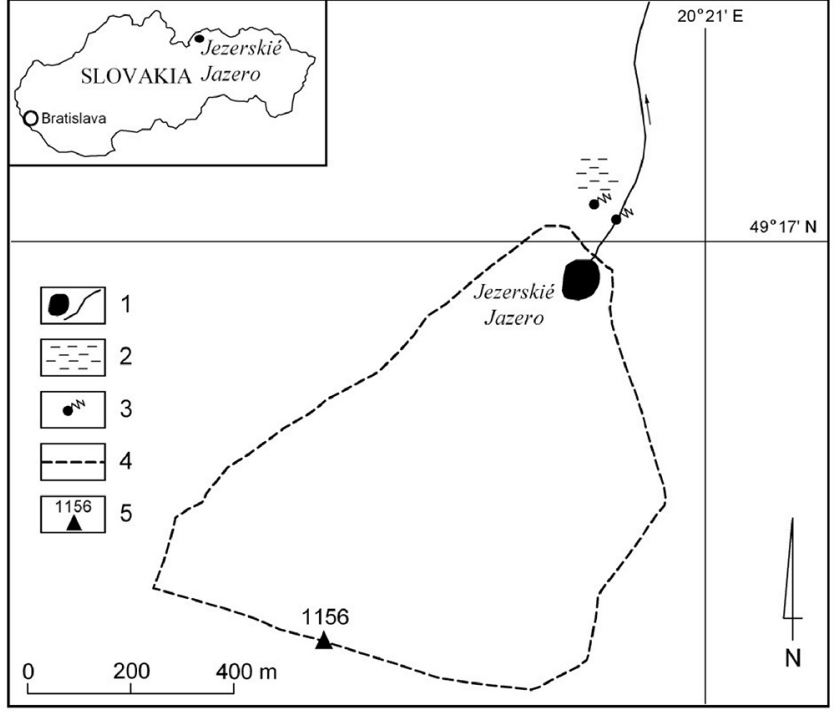

Fig. 1. Location of Lake Jazerske. Explanation: 1 - lake and stream, 2 - peat bog, 3 - springs, 4 - topographic drainage divide of the lake catchment

cal of medium-height mountains. Landslide processes play a significant role in modelling the slopes of this area. The lake is located at an altitude of $919 \mathrm{~m}$ a.s.l. It occupies a depression that was formed at the foot of the main scarp of the landslide. Below the lake, in the lower parts of the landslide colluvium, there are small intercolluvial depressions that are filled by peat bogs (Fig. 1). The lake is located in the Rieki River basin area. which is a right-bank tributary of the Dunajec ( $3^{\text {rd }}$ order). The object of the research along with the adjacent area is protected as the "Jazerske Jazero" Nature Reserve.

Lake Jazerske is located in the temperate transition climate zone, where the average annual temperature is $+5^{\circ} \mathrm{C}$. The coldest month is January $-4^{\circ} \mathrm{C}$ ) and the warmest is July $\left(+15^{\circ} \mathrm{C}\right)$. The average annual precipitation in the catchment of the lake is $1000 \mathrm{~mm}$. The highest precipitation, which amounts to $650 \mathrm{~mm}$, occurs in the warm half of the year (May-October. On average, snow cover in the catchment of the lake lasts for 90 days.

\section{Research methods}

Hydrographic mapping, which permits the water conditions in the lake catchment to be assessed, was conducted in accordance with the guidance of GutryKorycka and Werner-Więckowska (1996). Measurements of the basic physical and chemical properties of the water (temperature, $\mathrm{pH}$, electrical conductivity and water oxygen saturation) were performed in the field using an EDS 6600 multiparameter probe by YSI (US production). Before each study, the probe was calibrated using the standard solutions. These water parameters were determined in a water column in the lake every
0.5 metres. The profile was located at the deepest point of the lake. The study was conducted in all four seasons: spring (April) and autumn (November), i.e. during full mixing, as well as in summer (July) and winter (February).

During the field research, water samples for chemical analyses were also collected in polyethylene bottles. The samples represented the surface water layer $(0.5$ $\mathrm{m})$. Water from the surface layer was collected using a telescopic boom. The water samples were transported to the laboratory at a temperature of $+4^{\circ} \mathrm{C}$. Prior to the analyses, the samples were filtered on a $0.45 \mu \mathrm{m}$ filter (Millipore). Laboratory analyses included a determination of the major cations and anions in the water: $\mathrm{Ca}^{2+}$, $\mathrm{Mg}^{2+}, \mathrm{Na}^{+}, \mathrm{K}^{+}, \mathrm{HCO}_{3}^{-}, \mathrm{SO}_{4}^{2}, \mathrm{Cl}^{-}, \mathrm{NO}_{3}^{-}$and $\mathrm{PO}_{4}^{2-}$. The analyses were performed on a Metrohm 850 Professional IC ion chromatograph.

The depths of the lake were measured from a boat using LOWRANCE HDS-5 Gen2 sonar with a builtin GPS receiver. Based on the measurement results, a bathymetric plan was plotted as well as cross-sections using the computer program Dr Depth. The basic characteristics as well as the morphometric indicators of the lake (area, length, volume etc.) were calculated based on a topographic map on a scale of 1:10 000 and a bathymetric plan using the formulas that were developed by Choiński (2007).

\section{Results and discussion}

The studied lake is very small. Its area is $3600 \mathrm{~m}^{2}$ and its length is $85 \mathrm{~m}$. The lake basin is convex because the depth ratio (mean depth to maximum depth ratio) is greater than 0.33 . The course of the bottom contours is concentric and the deepest part is located in the central part of the lake (Fig. 2A). The maximum water depth in the lake is $7.2 \mathrm{~m}$. Because of its maximum depth, the lake definitely stands out from the other landslide lakes of the Western Carpathians. As was shown by numerous studies, the depths of this type of lake generally do not exceed a few metres (Nowalnicki 1976; Margielewski 1997). The underwater slopes of the lake are very steep and the average slope of the lake bottom is $15.5 \%$ (Fig. 2B). The capacity of the lake is $17000 \mathrm{~m}^{3}$.

In terms of its hydrology, Lake Jazerske is a drainage basin (Fig. 1). The lake is supplied by an inflow of groundwater (Fig. 3) via fractured aquifers. This type of water supply is characteristic of almost all of the lakes that occupy the deep depressions that have formed at the foot of the landslide main scarp (Koštalik 1999; Margielewski 1996; Obidowicz and Margielewski 2008). During periods of heavy rainfall and snow melting, the lake is also supplied by the water from surface runoff. On the main slope of the landslides, traces of 


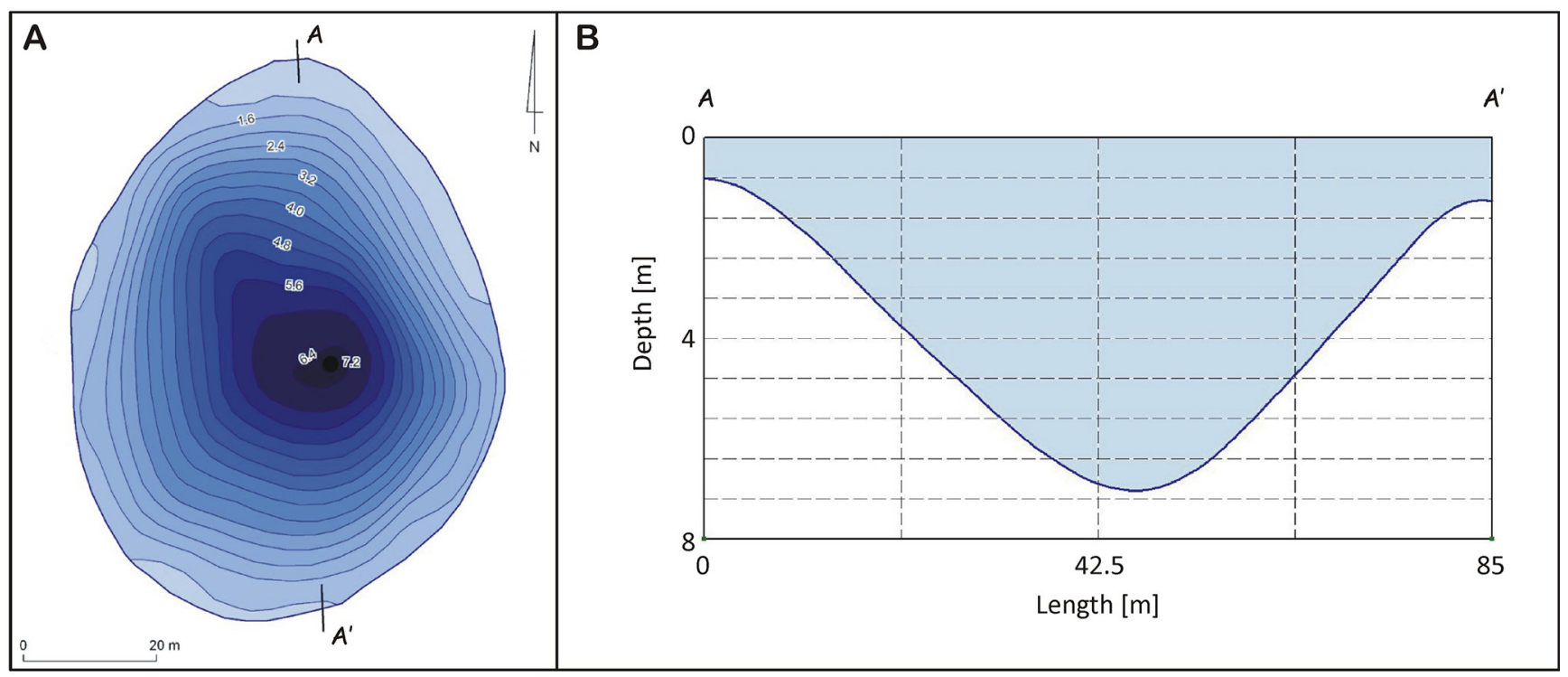

Fig. 2. Bathymetric map of Lake Jazerske (A) and north-south bathymetric profile of the lake basin (B)

ephemeral courses were also found. In periods of increased supply (spring snow melting, summer rainfall), the outflow of water from the lake occurs both on the surface and underground (Fig. 3). The same type of outflow was also found in the case of the landslide Lake Iwankowskie, which is located in the Gorce Mts. in Poland (Margielewski 1997; Bucała et al. 2014). The outflow from the lake water gives rise to a small watercourse that has a large hydraulic gradient, which caused the excision of a deep valley. During periods with a lower water supply (autumn, winter), there is no surface runoff and the outflow from the lake only occurs underground through intercolluvial drainage (Fig. 3). The water infiltrating from the lake comprises both channel springs and slope springs, which are located below the lake (Figs 1 and 3).

The electrolytic conductivity of the water flowing out of the lake ranged from 290 to $328 \mu \mathrm{S} \mathrm{cm}^{-1}$. During the summer and winter, an increase of electrolytic conductivity with depth was recorded (Fig. 4A). The conductivity of the bottom layer was 338 to $342 \mu \mathrm{S} \mathrm{cm}^{-1}$. An increase of conductivity with depth indicates an intense supply of groundwater with a higher mineralisation. Similar patterns were found in Lake Kielskie, which is also supplied by underwater springs (Choiński 2007). An intense groundwater supply may also be indicated by the course of oxygen profiles. In both summer and winter, there is a decrease in the oxygen concentration

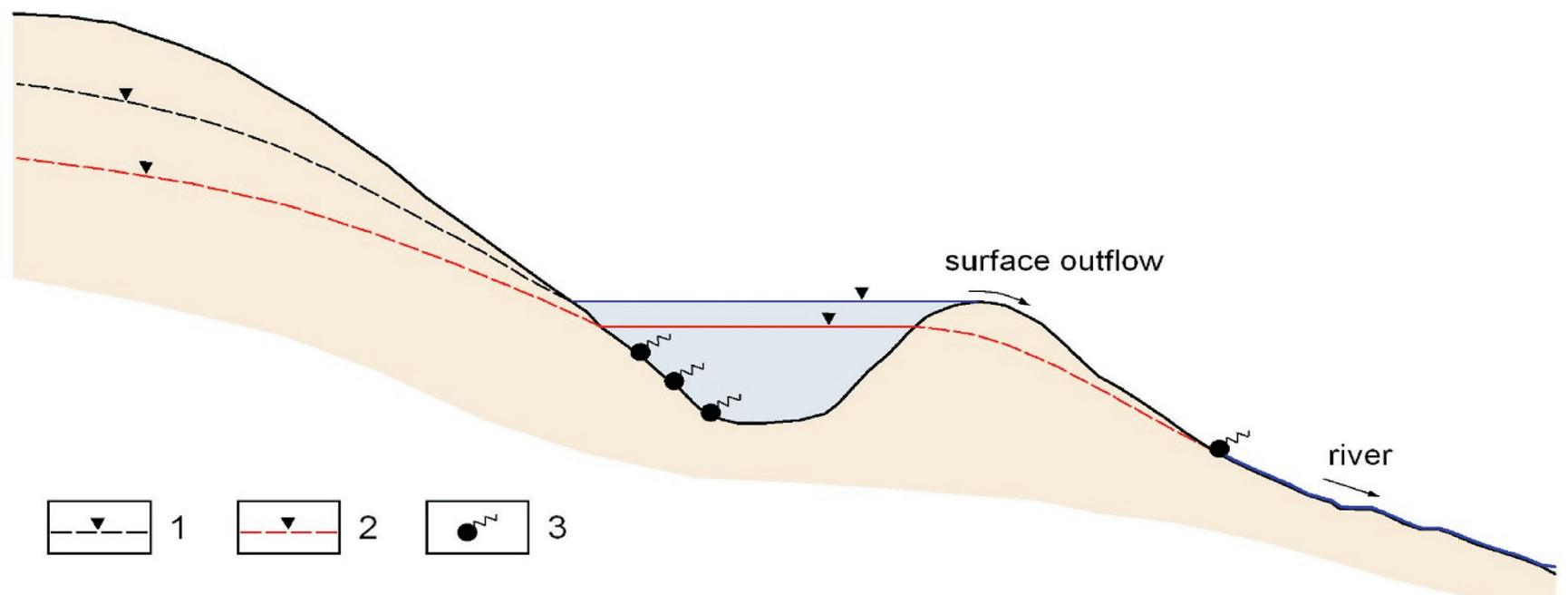

Fig. 3. Hydrogeological conditions of the lake: 1 - groundwater table during the period of increased water supply (spring, summer), 2 groundwater table during the autumn-winter season, 3 - springs 

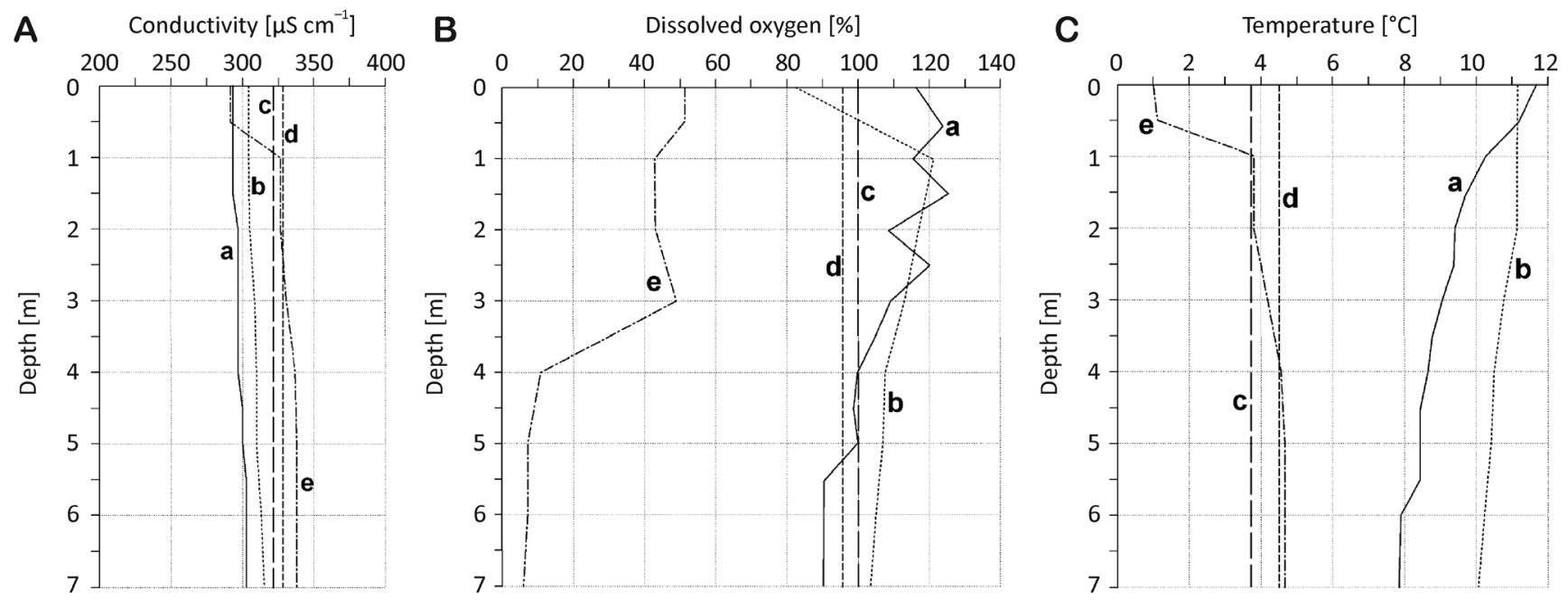

Fig. 4. Electrolytic conductivity (A), percentage of dissolved oxygen saturation (B) and temperature (C) depth profiles along water column of Lake Jazerske. Explanation: a - summer 2015, b - summer 2016, c - spring 2016, d - autumn 2016, e - winter 2016

with depth (Fig. 4B). This is due to the fact that the groundwater contains a small concentration of this gas (Macioszczyk 1987). In winter, the water oxygen saturation below $4 \mathrm{~m}$ was $<10 \%$. In spring and autumn during mixing, the water saturation with oxygen was good and oscillated between 90 and $110 \%$. The $\mathrm{pH}$ of the surface water of the lake was neutral and showed little variation over the year from 6.6 to $7.5 \mathrm{pH}$.

The thermal profiles in different seasons were interesting (Fig. 4C). In winter, the water temperature increases with depth. This is a situation that is characteristic of a catothermal structure, in which the temperature of the bottom water can reach $3.9^{\circ} \mathrm{C}$ (Choiński 2007). However, in the case of the studied object, the water temperature at the bottom was higher and was $4.7^{\circ} \mathrm{C}$. This was also a consequence of the underground supply. During the summer, there was a decrease in water temperature with depth. The temperature difference between the surface and bottom water layers was small and did not exceed $4^{\circ} \mathrm{C}$ (Fig. 4). In the analysed lake, it was impossible to delimit the zones that are characteristic of summer stagnation. The temperature of the surface water was low and never exceeded $12^{\circ} \mathrm{C}$. This was both a consequence of the location of the water body at a considerable height above sea level and the intense groundwater supply. During the summer, groundwater cools the limnic water down.

In terms of its hydrochemistry, the lake water represents the four-ion type - bicarbonate-sulphate-calci- um-magnesium. The same hydrochemical water type was also found in another landslide lake located in the area of the Spiš Magura (Molenda and Błońska 2015). The concentrations of various ions was characteristic of the shallow groundwater of the Carpathian flysch (Table 1). The concentration of major ions was low. This is due to the forest nature of the catchment area and the lack of anthropopression. The low variability of individual ion concentrations is characteristic of forest basins (Allan 1995; Policht-Latawiec et al. 2014). The predominant cation was calcium, the average concentration of which was $52 \mathrm{mg} \mathrm{dm}^{-3}$. The dominant anion was carbohydrates with an average concentration of $163 \mathrm{mg} \mathrm{dm}^{-3}$. Concentrations of chloride were very low, and did not exceed $2 \mathrm{mg} \mathrm{dm}^{-3}$. There were also very low sodium concentrations, namely below $3 \mathrm{mg} \mathrm{dm}^{-3}$. No evidence of orthophosphate ions $\left(\mathrm{PO}_{4}^{3-}\right)$ was found in the lake's water, which clearly demonstrates the absence of the types of anthropogenic influences that are associated with the inflow of sewage. The levels of nitrates $\left(\mathrm{NO}_{3}^{-}\right)$ were very low and did not exceed $5 \mathrm{mg} \mathrm{dm}^{-3}$. The water of another landslide lake (Lake Velke Ostrunanske), part of whose basin is used for agriculture, contained orthophosphate ions and a higher concentration of nitrates (Molenda and Błońska 2015).

Undoubtedly, due to its considerable depth and unusual thermal stratification, Lake Jazersko belongs to the unique objects of this genetic type in the Western Carpathians.

Table 1. Chemical composition of the Lake Jazerske waters ( $\min$ - max, average). Values are given in $\mathrm{mg} \mathrm{dm}^{-3}(\mathrm{n}=6)$

\begin{tabular}{|c|c|c|c|c|c|c|c|c|c|c|c|c|}
\hline \multicolumn{5}{|c|}{ Cations } & \multicolumn{8}{|c|}{ Anions } \\
\hline $\mathrm{Ca}^{2+}$ & $\mathrm{Mg}^{2+}$ & $\mathrm{Na}^{+}$ & $\mathrm{K}^{+}$ & $\mathrm{NH}_{4}^{+}$ & $\mathrm{HCO}_{3}^{-}$ & $\mathrm{F}^{-}$ & $\mathrm{Cl}^{-}$ & $\mathrm{NO}_{2}^{-}$ & $\mathrm{Br}$ & $\mathrm{NO}_{3}^{-}$ & $\mathrm{PO}_{4}^{3-}$ & $\mathrm{SO}_{4}^{2-}$ \\
\hline $\begin{array}{c}44-58 \\
48\end{array}$ & $\begin{array}{l}9-12 \\
10.5\end{array}$ & $\begin{array}{c}1.6-2.6 \\
1.8\end{array}$ & $\begin{array}{c}0.6-0.8 \\
0.7\end{array}$ & $\begin{array}{c}0.1-0.12 \\
0.11\end{array}$ & $\begin{array}{c}150-169 \\
155\end{array}$ & $\begin{array}{c}0.12-0.14 \\
0.13\end{array}$ & $\begin{array}{c}1.2-1.6 \\
1.5\end{array}$ & $\begin{array}{c}0.09-0.15 \\
0.11\end{array}$ & $\begin{array}{c}0.05-0.05 \\
0.05\end{array}$ & $\begin{array}{c}1.5-4.9 \\
4.4\end{array}$ & 0.0 & $\begin{array}{c}41-51 \\
44\end{array}$ \\
\hline
\end{tabular}




\section{References}

Alexandrowicz S.W., 1993, Late Quaternary landslides at Eastern periphery of the National Park of the Pieniny Mountains, Carpathians, Stud. Geol. Pol. 192: 209-225.

Alexandrowicz S.W. 1997, Holocene dated landslides in the Polish Carpathians, [in:] Matthews J.A., Brunsden D., Frenzel B., Gläser B., Weiss M.m. (eds), Rapid mass movement as a source of climatic evidence for the Holocene, Paläoklimaforschung - Palaeoclimate Research 19: $75-83$.

Alexandrowicz Z., Margielewski W., 2010, Impact of mass movements on geo- and biodiversity in the Polish Outer (Flysch) Carpathians, Geomorphology 123(2-3): 290304.

Allan J.D., 1995, Stream ecology. Structure and function of running waters, Chapman and Hall, London, 338 pp.

Bucała A., Margielewski W., Starkel L., Buczek K., Zernitskaya V., 2014, The reflection of human activity in the sediments of Iwankowskie lake from Subatlantic Phase (Polish Outer Carpathians), Geochronometria 41(1): 377-391.

Bober L., 1984, Rejony osuwiskowe w polskich Karpatach fliszowych i ich związek z budową geologiczną (Landslide areas in the Polish flysch Carpathians and their connection with the geological structure of the region), Biul. PIG 340: 115-158 (in Polish, English summary).

Choiński A., 2007, Limnologia fizyczna Polski (Physical limnology of Poland), Wydaw. Nauk. UAM, Poznań, 547 pp (in Polish).

Gutry-Korycka M., Werner-Więckowska H. (eds), 1996, Przewodnik do hydrograficznych badań terenowych (A guide to hydrographic field research), Wydaw. Nauk. PWN, Warszawa, 275 pp (in Polish).

Kardaszewska E., 1968, Osuwisko w Duszatynie (Landslide in Duszatyn), Ann. UMCS Sec. B 23(1): 1-26 (in Polish).

Koštalik J., 1999, Spišská Magura - geológia, reliéf, geoekológia (Spiš Magura - geology, relief, geoecology), Univerzita Pavla Jozefa Šafárika, Košice, 156 pp (in Slovak).

Macioszczyk A., 1987, Hydrogeochemia (Hydrogeochemistry), Wyd. Geol., Warszawa, 475 pp (in Polish).

Margielewski W., 1996, Jeziorka osuwiskowe Pasma Jaworzyny Krynickiej (Landslide ponds in the the Jaworzyna Krynicka Range), Probl. Zagosp. Ziem Górs. 40: 15-31 (in Polish, English summary).
Margielewski W., 1997, Ochrona jeziorek osuwiskowych w paśmie Lubania koło Ochotnicy Górnej (Protection of landslide dew ponds above Ochotnica Górna - Lubań Range), Chrońmy Przyr. Ojcz. 53(4): 74-84 (in Polish).

Margielewski W., 1999, Formy osuwiskowe Gorczańskiego Parku Narodowego i ich rola w kształtowaniu geo- i bioróżnorodności Gorców (Landslide forms in the Gorce National Park and their role in shaping geo- and biodiversity of the Gorce Range), Chrońmy Przyr. Ojcz. 55(4): 23-53 (in Polish).

Margielewski M., 2014, Torfowiska osuwiskowe polskich Karpat fliszowych jako czuły indykator zmian paleośrodowiska późnego glacjału i holocenu (Landslide peat bogs of the Polish Flysch Carpathians as a sensitive indicator of the palaeoenvironmental changes in the Late Glacial and Holocene), Stud. Lim. Tel. 8(1): 37-55 (in Polish, English summary).

Nowalnicki T., 1971, Beskidzkie jeziora zaporowe (Beskidian landslide lakes), Wierchy 40: 274-280 (in Polish).

Nowalnicki T., 1976, Jeziorka osuwiskowe w Beskidzie Sądeckim (Landslide ponds in the Beskid Sądecki Mts.), Wierchy 45: 182-198 (in Polish).

Obidowicz A., Margielewski W., 2008, Problematyka klasyfikacji torfowisk górskich (Problems of mountainous peat bogs classification), [in:] Żurek S. (ed.) Torfowiska gór, wyżyn i niżu (Peat bogs of highlands, uplands and lowlands), Wydaw. UJK, Kielce: 103-109 (in Polish).

Policht-Latawiec A., Kanownik W., Wójcik P., 2014, Jakość i walory użytkowe wody potoku fliszowego o niskiej presji antropogenicznej (Quality and usable values of water of flysch stream with low anthropopressure), Infrastruktura i ekologia terenów wiejskich 3(1): 917-929 (in Polish, English summary).

Pánek T., Smolkova V., Hradecky J., Kirchner K., 2007, Landslide dams in the northern part of Czech Flysch Carpathians: Geomorphic evidence and imprints, Stud. Geomorph. Carpatho-Balcanica 41: 77-96.

Schramm W., 1925, Zsuwiska stoków górskich w Beskidzie. Wielkie zsuwisko w lesie wsi Duszatyn ziemi Sanockiej (Landslides of mountain slopes in Beskids. The large landslide in the forest of Duszatyn village), Kosmos 50(4): 1355-1374 (in Polish, French summary).

Zatorski M., Buczek K., Franczak P., 2016. The structural control of a landslide development and functioning of a lake geoecosystem in the catchment area of the Hucianka Stream (the Outer Carpathians, Beskid Niski), Limnol. Rev. 15(3): 129-142. 